\title{
APPLYING DIGITAL STORYTELLING TO IMPROVE INDONESIAN HIGH SCHOOL STUDENTS' VISUAL MEMORY AND WRITING SKILL
}

\author{
Imam Sudarmaji \\ Department of English Language Education, Faculty of Teacher Training and Education \\ Universitas Islam Syekh-Yusuf, Indonesia \\ E-mail: isudarmaji@unis.ac.id \\ Agus Mulyana \\ Department of English Language Education, Faculty of Teacher Training and Education \\ Universitas Islam Syekh-Yusuf, Indonesia \\ E-mail: amulyana@unis.ac.id \\ Karsiyah \\ Department of English Language Education, Faculty of Teacher Training and Education \\ Universitas Islam Syekh-Yusuf, Indonesia \\ E-mail: karsiyahvl@gmail.com
}

\begin{abstract}
APA Citation: Imam, S., Mulyana, A., \& Karsiyah (2020). Applying digital storytelling to improve Indonesian high school students' visual memory and writing skill. English Review: Journal of English Education, 8(2), 255-264. doi: 10.25134/erjee.v8i2.2987.
\end{abstract}

Received: 12-02-2020

Accepted: 02-04-2020

Published: 01-06-2020

\begin{abstract}
This study investigated the use of digital storytelling in improving students' visual memory and writing skill of tenth grade students in one of senior high school in Tangerang, Indonesia. A total of 72 students are taken as the sample in the current study. The randomized pretest - posttest control group design was used in the study. Using quasi experimental research-non-equivalent control group design, the students in the experimental groups completed the process through digital storytelling. The students' test and questionnaires were used to collect the data. In order to test whether there was an improvement within groups and to see if there were differences between groups, the hypotheses were tested using the t-test and obtaining gain scores. The result showed that the visual memory and writing skill of students undergoing digital storytelling technique and of those undergoing conventional teaching but no significant differences were found between the two conditions. They had same proficiency, focused and same concentration during the learning process, and the students had many opinions in experimental class. Based on the percentages, students' post-test showed that students' visual memory was more dominant than students' writing skill after applying digital storytelling. Moreover, this research also found that students' learning motivation was very good and created a good of class atmosphere in experimental class during the learning process by using digital storytelling.
\end{abstract}

Keywords: digital storytelling; visual memory; writing skill.

\section{INTRODUCTION}

In the acquisition and fluency of language skills may be directly involved visual memory. Magnussen (2009), said that memory is retain stimulus information in memory which is assessed in term precision. Visual memory is one of the ability to remember or recall such as images, scenes, words, and other information which presented visually. Visual memory is important to develop, because according to Phillips \& Christie (2013), visual memory has a role in a wide variety of everyday tasks. It has also been considered fundamental on every type of academic learning. The students should be able to visualize the stimulus in their mind.
Visual memory is a complex process for students. Current theory of visual working memory involving capacity and resolution as the two important aspects of visual working memory storage (Yao, Chen, and Qian 2018). The memory storage system of working memory includes subsystems. They maintain verbal, spatial, and visual information. The feel is so hard to remember with what they have seen, so the students should learn and understand the ability to store and recall mental images in the memory efficiently to help their learning a foreign language (Michel et al. 2019). This memory will store in short-term memory, as many as students should remember with the duration is briefly to 
see. According to Baddeley et al., (2015) that short-term memory is able to store limited quantities of information for limited periods of time. So if the students' did not pay attention, they will feel difficult in placing visual which means that they need stimuli for be able to visualize. The students may have difficulty during several operations such as remembering general view of words in reading and writing, also sequencing the letters if such skills have not improved.

While, writing is one of the four skills in English. The students felt that writing is as more complicated than the other skills and became challenging area of language learning (Jabali 2018). Javed et al., (2013) said that even native speakers of English can feel difficulty in demonstrating a good of writing. The students often feel confused when they are using the rules of writing such as grammatical and they also lack of vocabulary. According to Ma'azi \& Janfeshan (2018) and Nik et al., (2010) said that writing has an important role which is assumed as the most complex process. Sylvester \& Greenidge (2009) stated that writing has difficulty to start and it is a very complex process to write, although after the teacher assists the students for prewriting activities such as brainstorming to generate the ideas or supports an upcoming writing assignment. Learning to write is a difficult and complex process because it concerned with the knowledge about the structure of language Rusinovci (2015). Students also need to know how to express their idea, feeling, opinion, critical thinking in written text (Fadhly 2014).

The students still do not understand how to write in English and they don't know their mistakes on their writing. The technique or strategies to teach writing may not be interesting for the students. Klimova (2014) claimed that if the teacher uses appropriate technique/strategies to teach the students, it can be more interesting and considers students' personality. Writing instruction in language teaching and learning can improve students' writing skill (Coker et al. 2018). Teacher should pay attention to the students' writing strategies and the types of writing instructions (Bai 2018; Palermo and Thomson 2018)

The current advancement in the information and communication technology (ICT) or digital era has provided the learners with various tools with the form of computer-based or Internetbased resources. Many teachers now use digital tools in addition to other instruction methods and not as a substitute learning (Hillmayr et al. 2020). Digital Learning can help students take charge of their own learning and make them fun (Schmoelz 2018; Zwart et al. 2020). The use of digital technology can amplify this experience and provide a concrete support in the development of language and communication skills (Rubegni and Landoni 2018; Thang et al. 2014). One of the technique in language teaching is digital storytelling (DST). DST technique helps students develop their better language skills and this technique can be considered as an essential tool in foreign language learning and teaching (Razmi, Pourali, and Nozad 2014).

DST which combines the characteristic of storytelling with different interactive media tools can benefit language learning in a variety of ways. It was found to encourage and motivate students and at the same time enhance their communication skills (Ciğerci and Gultekin 2017; Thang et al. 2014). DST helps students to find, apply, learn, and share each other various amount of vocabulary and moreover helps them to think critically due to the limitation of script writing and presented digitally (Tajeri, Syal, and Marzban 2017). Teachers can provide students a sharing experience to enhance learning through seeing, hearing, and feeling (Beck and Sitzman 2019).

DST is also a good technique that suitable for the students to teach visual memory and writing, also can help the students to improve their visual memory capacity and writing skill (Sarica and Usluel 2016). Some researchers said that digital storytelling gives positive effect for the students. According to Gallets (2005) that through storytelling, students can be more thinking and imaginative skill. Also their mental process played more active role. Story will influence memory, and the storytelling can facilitate students' cognitive changes (Schank and Abelson 1995). Besides visual memory, digital storytelling can be used as an effective learning tool to improve students' writing skill (Xu et al., 2011; Campbell, 2012; Yang \& Wu, 2012; Sarica \& Usluel, 2016; Yamaç \& Ulusoy, 2016; Tarigan \& Liana, 2018). Abdel-Hack \& Helwa (2014) also said that through digital storytelling, narrative writing and critical thinking skills were developed.

In the latest decade, many researcher conducted the research to investigate the use of digital story telling in language learning. First, Eman Mohamed \& Hasnaa Sabry, (2014) had a research which investigated the effectiveness of using digital storytelling and Weblogs instruction 
in enhancing EFL narrative writing and critical thinking skills among EFL majors at Faculty of Education. The result showed that using digital storytelling and Weblogs instruction is effective in enhancing the EFL narrative writing and critical thinking skills among EFL majors at Faculty of Education. Second, Sarica \& Usluel, (2016) investigated the effect of digital storytelling on the visual memory capacity and writing skills of students in primary school. Then, Tarigan \& Liana, (2018) conducted the research to examine the effectiveness of using digital story telling in teaching writing skill of students in higher education or university. The result showed that the students' writing skill are improved after implementing digital story telling as the teaching media. The study showed that digital story telling is effective to enhance students' writing skill. The previous research focus on the subject in primary school and university. The current study intend to confirm the use of digital storytelling as a language teaching technique in foreign language class in senior secondary school. The focus of the study is to know whether there is any significant effect of digital storytelling on the students' visual memory and writing skill, to know which one is more dominant between students' visual memory and writing skill, and to know how the students' learning motivation and class atmosphere through applying digital storytelling.

\section{METHOD}

This study used experimental method. The design of this study was a quasi-experimental researchnon-equivalent control group design. The researcher chose this design, because according to Fraenkel et al., (2012) there were two different classes' treatment, namely experimental class and control class, and do not include the use of random assignment. This study was conducted by the researcher who taught in two different classes, namely experimental class and control class. Where experimental class was the class that applied by using digital storytelling, and control class that applied by using conventional teaching (gallery walk).

\begin{tabular}{cccc}
\multicolumn{4}{c}{ Table 1. Research design } \\
\hline Class & Test & Treatments & Test \\
\hline EC & Pre-test & X1 & Post-test \\
& O1a & & O1b \\
CC & Pre-test & Xost-test \\
& O2a & X2 & O2b \\
\hline \multicolumn{4}{c}{ Source: Processed Primary Data (2019) }
\end{tabular}

Information:

$\begin{array}{ll}\mathrm{EC} & =\text { experiment class } \\ \mathrm{CC} & =\text { control class } \\ \mathrm{O} 1 \mathrm{a} & =\text { pre-test at experiment class } \\ \mathrm{O} 2 \mathrm{a} & =\text { pre-test at control class } \\ \mathrm{X} 1 & =\text { DST technique application } \\ \mathrm{X} 2 & =\text { conventional technique } \\ & \text { application } \\ \mathrm{O} 1 \mathrm{~b} & =\text { learning outcomes of experiment } \\ & \text { class after treatment } \\ \mathrm{O} 2 \mathrm{~b} & =\text { learning outcomes of control }\end{array}$

The population of this study was all of students in tenth grade in one senior high school in Tangerang in Academic Year 2019/2020. While, the sample was students in MIPA (Science Class) 1 as the experimental group and MIPA (Science) Class 2 as the control group. The researcher chose the sample based on the previous information, their proficiency, and their relevancy with the study purpose.

The data of this study was quantitative data. The quantitative data were obtained by the scores of students' task from pre-test and post-test. Writing test instrument and questionnaire are used to collect the data. After the students' visual memory and writing scores had been collected, the researcher analyzed the data using one paired t-test to see the comparison between pre-test and post-test mean scores and to see the effect of using digital storytelling on students' visual memory and writing skill. It also enabled the researcher to know the dominant between visual memory and writing skill after applying digital storytelling. While, questionnaire were used to know the added value that wanted to be known in the achievement of students' learning outcomes was the students' learning motivation and class atmosphere.

\section{RESULTS AND DISCUSSION}

The classroom observation data showed that the result of experimental class and control class. In experimental class, the researcher started by giving materials about narrative text and how to write narrative text by using digital, it such as by Power Point. Then, show the videos of the stories including with the sound system. After students watched, some pictures of the stories showed to them. They have to remember and understand of the story and can re-write the story of narrative text that they remembered. While, in control class the researcher gave the material about narrative text and how to write it by using conventional teaching (gallery walk). They have to remember 
and understand on it. The researcher rewrite the sample of story by written on the whiteboard. Then, asked the students to rewrite the story of narrative text that they remembered.

This research also measured the level of motivation of students after learning by using digital storytelling technique. Questionnaire of learning motivation that has been given to the students in experimental class during the learning process. Besides measuring of the learning motivation, researcher also measured the level of the class atmosphere. The score of class atmosphere was obtained from questionnaire that has been given to the students in experimental class during the learning process by using digital storytelling technique.

\section{Students' score of visual memory}

The students' score in experimental class and control class are increased. As the Minimum Mastery Criterion (KKM) at the tenth grade is 67. Based on the result that there was no students not pass on visual memory in experimental class that taught by using digital storytelling technique. $100 \%$ students can pass KKM values means the students got the score than 67 as KKM values.

While, based on the visual memory test that was given in control class the researcher got the total score was $11 \%$ students could not pass KKM values and $89 \%$ students could pass KKM values. It means, almost all of students in control class have score more than 67. Even though there are several students got the score gain with KKM values.

\section{Students' score of writing skill}

The students' score in experimental class and control class are increased, but many students have a score below the minimum criteria (KKM). In experimental class $42 \%$ students could not achieve KKM values and 58\% students could achieve KKM values. While, in control class 56\% students could not achieve KKM values and 44\% students could achieve KKM values. It can be seen from graphic below:

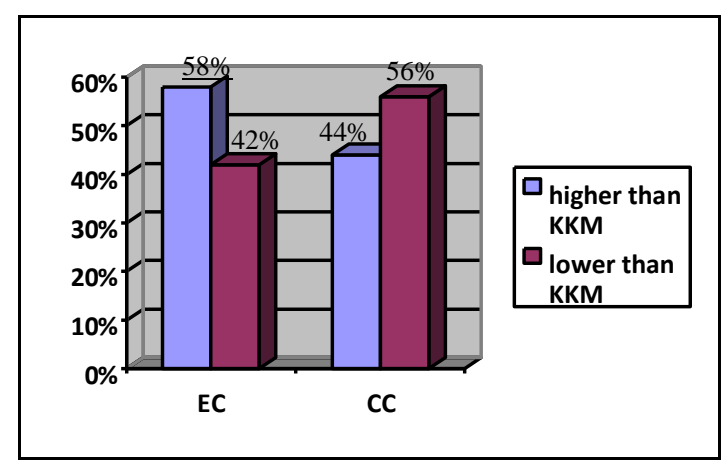

Figure 1. Students' post-test in experiment and control class

\section{Students' learning motivation in experimental class}

In this research, the students' learning motivation which measured by criteria that is consists of $1 \%$ $-20 \%=$ bad, $21 \%-40 \%=$ not good, $41 \%-60 \%$ $=$ sufficient, $61 \%-80 \%=$ good, $81 \%-100 \%=$ very good. This research analyzed by obtaining the total score of learning motivation, and got the total was 2321. So, based on the criteria of percentages that can be categorized that the students' learning motivation was very good during the learning process by using digital storytelling with percentages $81 \%$.

\section{Class atmosphere in experimental class}

The questionnaire of class atmosphere has six statements which is given by the researcher to know the students' perception and participation about class atmosphere during the learning process. The result of every statements can be explained as follows:

\section{Class atmosphere}

The criteria of class atmosphere can be categorized by successive interval became 3 points with the higher score was 4,204 means the students answered good, 2,621 means the students answered sufficient, and the lower was 1,000 means the students answered bad. This research got the students' answer as the following table:

Table 2. Atmosphere class in experimental class

\begin{tabular}{cccc}
\hline Categories & $\begin{array}{c}\text { Total of } \\
\text { Students }\end{array}$ & Percentages & Answer \\
\hline $1-1,40$ & 4 & $11 \%$ & Bad \\
$1,42-2,81$ & 26 & $72 \%$ & Sufficient \\
$2,82-4,22$ & 6 & $17 \%$ & Good \\
\hline \multicolumn{4}{c}{ Source: Students' questionnaire data }
\end{tabular}


Based on the table above, it can be explained that the students who answer bad was 4 students with the percentages $11 \%, 26$ students who answer sufficient with the percentages $72 \%$, and the last, the students who answer good was 6 students with the percentages $17 \%$. It can be concluded that the students are more dominant answer sufficient. So, the researcher find out during the learning process by digital storytelling was sufficient.

\section{The students do not understand during the learning process}

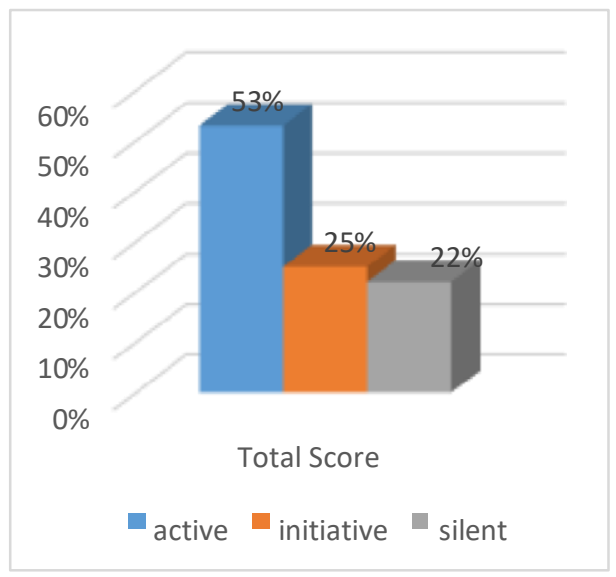

Figure 2. Students' participation of class atmosphere

The students who do not understand the material during the learning process would: 1) raise their hand and asked for more explanation was $53 \%$ can be categorized as the students active, 2) went to teacher after class to ask for more explanation was $25 \%$ can be categorized as the students initiative, and 3) did nothing was $22 \%$ can be categorized as the students silent.

\section{Time passed most quickly during the learning process}

During the learning process, time passed most quickly for students. The answer from the statement contained of 3 answers were: 1) the teacher was teaching $\mathrm{him} /$ herself was $25 \%, 2$ ) students solved the problem by themselves was $56 \%$, and 3) the students did the exercise individually was $25 \%$.

Students disagree with the teacher or they have a comment

The answer from the statement contained 3 answers were: 1) students said that immediately was $61 \%$ can be categorized as an active students, 2) students waited until after class and told it to the teacher was $25 \%$ can be categorized an initiative students, and 3) students remained silent was $14 \%$. The following graphic explained about the students disagree when they have an argument during the learning process:

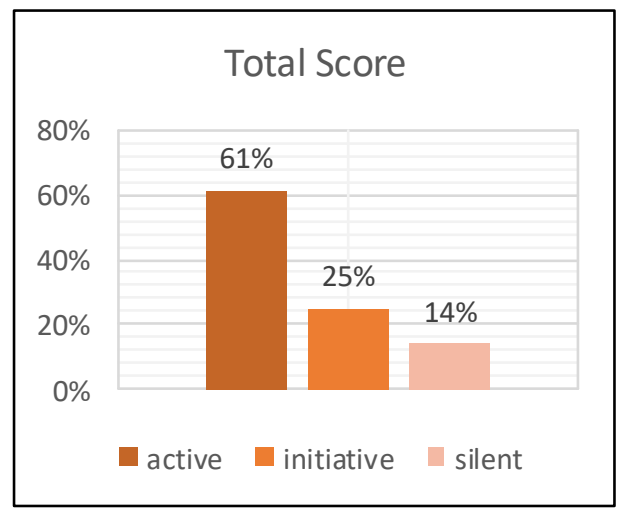

Figure 3. Students disagree in learningprocess

\section{The teacher who teach with the conventional learning}

The answers from the statement contained 3 answers were: 1) students can easily follow without having friend disturbing them was $44 \%$, 2) students talked to fellow students about how they experienced the course after class was $42 \%$, 3 ) there was at least no turmoil as we don't have to work together was $14 \%$.

\section{The process during learning in class}

The criteria of the process during learning in class categorized by successive interval became 3 points with the higher score was 3,530 means the students answered lot, 2,214 means the students answered sufficient, and the lower score was 1,000 means the students answered nothing. The process during learning in class got the students' answer as the following table:

Table 3. The process during learning in class

\begin{tabular}{cccc}
\hline Categorizes & $\begin{array}{c}\text { Total of } \\
\text { Students }\end{array}$ & $\begin{array}{c}\text { Percentage } \\
\text { s }\end{array}$ & Answer \\
\hline $1-1,18$ & 5 & $14 \%$ & Nothing \\
$1,19-2,37$ & 16 & $44 \%$ & Sufficient \\
$2,38-3,56$ & 15 & $42 \%$ & Lot \\
\hline \multicolumn{4}{r}{ Source: Students' questionnaire data }
\end{tabular}

From the table above explained that the students who answered nothing was $14 \%$, the students who answered sufficient was $44 \%$, and the students who answered lot was $42 \%$.

Based on analyzed from sixth statements above that has been explained one by one can be 
concluded overall by obtaining the total score with the criteria of class atmosphere were $1 \%$ $33 \%=$ bad, $34 \%-67 \%=$ sufficient, and $68 \%-$ $100 \%=$ good. This research got the total score from the questionnaire data was 439,744 that can be categorized was $68 \%$ which means the class atmosphere using digital storytelling was good with the students were active during learning process such as students ask to the teacher for more explanation, also when they have an argument and disagree about the material with at least of students remained silent.

After knowing that the data was normal and homogeneous because the significance was more than 0,05 , for the further testing the researcher testing hypotheses test (t-test).

Table 4. Independent sample test

\begin{tabular}{|c|c|c|c|c|c|c|c|c|c|}
\hline \multirow{3}{*}{ Assumption } & \multicolumn{4}{|c|}{$\begin{array}{l}\text { Levene's Test } \\
\text { for Equality } \\
\text { of Variances }\end{array}$} & \multicolumn{3}{|c|}{ t-test for Equality of Means } & & \\
\hline & \multirow[t]{2}{*}{ F } & \multirow[t]{2}{*}{ Sig. } & \multirow[t]{2}{*}{$\mathrm{t}$} & \multirow[t]{2}{*}{ Df } & \multirow[t]{2}{*}{$\begin{array}{l}\text { Sig. (2- } \\
\text { tailed) }\end{array}$} & \multirow[t]{2}{*}{$\begin{array}{c}\text { Mean } \\
\text { Difference }\end{array}$} & \multirow[t]{2}{*}{$\begin{array}{l}\text { Std. Error } \\
\text { Difference }\end{array}$} & \multicolumn{2}{|c|}{$\begin{array}{l}\text { 95\% Confidence } \\
\text { Interval of the } \\
\text { Difference }\end{array}$} \\
\hline & & & & & & & & Lower & Upper \\
\hline $\begin{array}{l}\text { Equal variances } \\
\text { assumed }\end{array}$ & .605 & .439 & -1.425 & 70 & .159 & -6.389 & 4.484 & -15.331 & 2.554 \\
\hline $\begin{array}{l}\text { Equal variances } \\
\text { not assumed }\end{array}$ & & & -1.425 & 68.439 & .159 & -6.389 & 4.484 & -15.335 & 2.557 \\
\hline
\end{tabular}

Source: Statistical result SPSS 25

In this research, the researcher used statistical calculating of t-test formula to find out the effect of using digital storytelling in teaching narrative text on the students' visual memory. The researcher analyzed the result 72 of the differences score experimental class and control class. The alternative hypotheses $(\mathrm{Ha})$ stated that there is no significant differences between experimental class that using digital storytelling and control class that using gallery walk. In this data analyzed, the researcher used t-test and the result of them consulted with the t-table.

Based on the table above, it is know $-t_{\text {count }}$ $>-t_{\text {table }}(-1,425>-1,994)$ with sig $=0,159>$ 0,05 , it can be concluded that Ho is accepted and $\mathrm{Ha}$ is rejected, it means there is no significant differences of visual memory between experimental class and control class at the tenth grade of high school in Tangerang.

Table 5. Independent Sample Test

\begin{tabular}{|c|c|c|c|c|c|c|c|c|c|}
\hline \multirow{3}{*}{ Assumption } & \multicolumn{4}{|c|}{$\begin{array}{l}\text { Levene's Test } \\
\text { for Equality } \\
\text { of Variances }\end{array}$} & \multicolumn{3}{|c|}{ t-test for Equality of Means } & & \\
\hline & \multirow[t]{2}{*}{$\mathrm{F}$} & \multirow[t]{2}{*}{ Sig. } & \multirow[t]{2}{*}{$\mathrm{t}$} & \multirow[t]{2}{*}{ Df } & \multirow[t]{2}{*}{$\begin{array}{l}\text { Sig. (2- } \\
\text { tailed) }\end{array}$} & \multirow[t]{2}{*}{$\begin{array}{c}\text { Mean } \\
\text { Difference }\end{array}$} & \multirow[t]{2}{*}{$\begin{array}{l}\text { Std. Error } \\
\text { Difference }\end{array}$} & \multicolumn{2}{|c|}{$\begin{array}{l}\text { 95\% Confidence } \\
\text { Interval of the } \\
\text { Difference }\end{array}$} \\
\hline & & & & & & & & Lower & Upper \\
\hline $\begin{array}{l}\text { Equal variances } \\
\text { assumed }\end{array}$ & .431 & .513 & -1.639 & 70 & .106 & -4.556 & 2.779 & -10.099 & .988 \\
\hline $\begin{array}{l}\text { Equal variances } \\
\text { not assumed }\end{array}$ & & & -1.639 & 69.291 & .106 & -4.556 & 2.779 & -10.100 & .989 \\
\hline
\end{tabular}

In this research, the researcher used statistical calculating of t-test formula to find out the effect of using digital storytelling in teaching narrative text on the students' writing skill. The researcher analyzed the result 72 of the differences score experimental class and control class. The alternative hypotheses $(\mathrm{Ha})$ stated that there is no significant differences between experimental class that using digital storytelling and control class that using gallery walk. In this data analyzed, the researcher used t-test and the result of them consulted with t-table.

Based on the table above, it is known $-t_{\text {count }}>-t_{\text {table }}(-1,639>-1,994)$ with sig $=$ $0,106>0,05$, it can be concluded that Ho is accepted and $\mathrm{Ha}$ is rejected, it means there is no significant differences of writing skill between 
experimental class and control class at the tenth grade of high school in Tangerang. So, digital storytelling that applied by the researcher has no difference to improve the students' writing skill at the tenth of high school in Tangerang.

From the students' analysis of visual memory and writing skill taught by using digital storytelling in experimental class and by using gallery walk in control class, the researcher has found the result of students' visual memory and writing skill. The researcher have just given the pre-test, treatment, and post-test in order to know the students' visual memory and writing skill.

The result of teaching visual memory and writing skill taught by the researcher using digital storytelling technique was good, because the students' scores are increased between pre-test and post-test score. So, their visual memory and writing skill had improved. The score of post-test was higher than pre-test. In visual memory $100 \%$ students can pass KKM values and in writing skill $58 \%$ students can pass KKM values. Based on the percentages, students' post-test of visual memory is more dominant than writing skill after applying digital storytelling technique.

The testing of research hypotheses indicated that $\mathrm{Ho}$ is accepted and $\mathrm{Ha}$ is rejected, it means there is no significant difference of using digital storytelling on the students' visual memory and writing skill. This research is related with the previous research such as from Sarica \& Usluel (2016) about visual memory that is no statistical difference was found that the students less interaction with visuals in experimental class than control class. But, this research did not correspond to Sarica \& Usluel (2016) for writing skill that can be said the significant result to improve writing skill of students in experimental and control class. Also from Yamaç \& Ulusoy (2016) stated that through digital storytelling could successfully result in improvement students' writing skill. Tarigan \& Liana (2018) said that the students' writing skill after using digital storytelling technique was significantly higher than before their used. Although fundamentally that visual memory need to take a long time to develop, because the development of memory capacity begins in infancy and continues through early adulthood (Terry, 2009). While, also for writing is assumed the most difficult to be learnt by the students. As Brown (2007) stated that there are many aspects that can be assessed when the teachers measure the students' writing skill such as content, organization, grammar, vocabulary, mechanic and the score of writing test was taken based on proficiency categories.

In this research, there is no different between experimental and control class. Although there is no activities related to the digital storytelling were conducted in control class, because the condition of the students were same and had same proficiency. They focused and had concentration when researcher/teacher taught the students either by digital storytelling or gallery walk, but the students have many opinions in experimental class. So that the learning outcomes obtained almost same or have no different.

Based on this matter, the researcher conducted by giving questionnaire to get the students' learning motivation and atmosphere class during the learning process in experimental class by using digital storytelling technique. The result showed that the application of this technique had proven to have a very good effect in increasing learning motivation. In addition, this technique also could create a good and conducive classroom atmosphere, students active to ask and students able to solve problem. Witte \& Rogge (2014) stated that if the students are active during the learning process, so the technique has positive effect and it can believe the students' learning motivation and class atmosphere were better.

\section{CONCLUSION}

The students' score of visual memory in experimental class are increased after applying digital storytelling. The students' score of posttest was higher that pre-test, it was 100\% students can pass KKM (Minimum Mastery Criterion) values. While, the students' score of writing skill in experimental class also increased after applying digital storytelling. The score of posttest was higher than pre-test, it was 58\% students can pass KKM values. So, the level of achievement of the KKM values from these had improved.

Based on the percentages of students' posttest score that visual memory was more dominant than writing skill after applying digital storytelling at the tenth grade students of higher school in Tangerang in academic year 2019/2020.

The result of statistic which obtained by analyzing data through t-test of statistic calculation, it indicated that Ho is accepted and $\mathrm{Ha}$ is rejected which means that there is no significant difference of using digital storytelling on the students' visual memory and writing skill at the tenth grade of higher school in Tangerang. 
Some factors influenced no statistical difference between experimental class and control class due to the condition of students were same proficiency, and from both of classes that the students focused and had concentration when the teacher giving the materials either by digital storytelling or gallery walk, also the students in experimental have many opinions during the learning process. So, that the learning outcomes were same or no have different.

Although there is no statistical different, digital storytelling can contribute in experimental class. It can be proved from the students' questionnaire showed that the students' learning motivation was very good and created a good class atmosphere. Almost all of students are interested with the technique of teaching and they are active during the learning process by using digital storytelling.

\section{REFERENCES}

Abdel-Hack, E. M., \& Helwa, H. S. A. A. (2014). Using digital storytelling and weblogs instruction to enhance EFL narrative writing and critical thinking skills among EFL majors at faculty of education. International Research Journal 5(1):8-41.

Baddeley, A. Eysenck, M. W., \& Anderson, M. C. (2015). Memory ( $2^{\text {nd }}$ ed.) London: Psychology Press.

Bai, B. (2018). Understanding primary school students' use of self-regulated writing strategies through think-aloud protocols. System, 78, 1526.

Beck, M. S., \& Sitzman. K (2019). Compelling reasons for using digital stories to teach: A descriptive qualitative study. Teaching and Learning in Nursing, 14(4), 265-269.

Campbell, T. A. (2012). Digital storytelling in an elementary classroom: Going beyond entertainment. Procedia Social and Behavioral Sciences 69 (Iceepsy), 385-393.

Ciğerci, F. M., \& Gultekin. (2017). Use of digital stories to develop listening comprehension skills. Issues in Educational Research, 27(2), 252-268.

Coker, D. L., Austin, S. J., Elizabeth, F. R., \& MacArthur, C. A. (2018). When the type of practice matters: The relationship between typical writing instruction, student practice, and writing achievement in first grade. Contemporary Educational Psychology 54(June), 235-46.

Eman, M., Abdel-Hack, \& Abdel-Hamid A. H. H. S. (2014). Using digital storytelling and weblogs instruction to enhance EFL narrative writing and critical thinking skills among EFL majors at faculty of education. International Research Journal, 5(1), 8-41.
Fadhly, F. Z.. \& Nurendah. (2014). Applying scientific approach to enhance Indonesian EFL learners' descriptive writing. English Review: Journal of English Education, 1(2), 114-124.

Fraenkel, J. R., Wallen, N. E., \& Helen, H. (2012). How to design and evaluate research in education ( $8^{\text {th }}$ ed.). New York: McGraw-Hill.

Gallets, M. P. (2005). storytelling and story reading: A comparison of effects on children's memory and story comprehension. ProQuest Dissertations and Theses. Tennesse: East Tennessee State University.

Hillmayr, D., Ziernwald, L., Reinhold, F., Sarah I. H., \& Reiss, K. M. (2020). The potential of digital tools to enhance mathematics and science learning in secondary schools: A context-specific meta-analysis. Computers and Education 153(2), 103897.

Jabali, O. (2018). Students' attitudes towards EFL university writing: A case study at An-Najah national university, Palestine. Heliyon, 4(11).

Javed, M., Wu, X. J., \& Nazli, S. (2013). A study of students' sssessment in writing skills of the English language. International Journal of Instruction, 6(2).

Klimova, B. F. (2014). Constraints and difficulties in the process of writing acquisition. Procedia Social and Behavioral Sciences, 122, 433-437.

Ma'azi, H., \& Janfeshan. K. (2018). The effect of edmodo social learning network on Iranian EFL learners writing skill. Cogent Education, 5(1), 117.

Magnussen, S. (2009). Implicit visual working memory. Scandinavian Journal of Psychology 50(6).

Michel, M., Kormos, J., Brunfaut, T., \& Ratajczak, M.. (2019). The role of working memory in young second language learners' written performances. Journal of Second Language Writing 45(March), 31-45.

Nik, Y. A., Hamzah, A., \& Hasbollah, H. (2010). Why writing in ESL is difficult for undergraduates in a public university in Malaysia. Journal of Language Teaching and Research, 1,1-7.

Palermo, C., \& Thomson, M. M. (2018). Teacher implementation of self-regulated strategy development with an automated writing evaluation system: Effects on the argumentative writing performance of middle school students. Contemporary Educational Psychology 54(2), 255-70.

Phillips, W. A., \& Christie, D. F. M. (2013). Components of visual memory. Quarterly Journal of Experimental Psychology, 29(1), 117-33.

Razmi, M., Pourali, S., Nozad, S. (2014). Digital storytelling in EFL classroom (Oral presentation of the story): A pathway to improve oral production. Procedia - Social and Behavioral Sciences, 98(2011), 1541-44. 
ENGLISH REVIEW: Journal of English Education

Volume 8, Issue 2, June 2020

Rubegni, E., \& Landoni, M. (2018). How to design a digital storytelling authoring tool for developing pre-reading and pre-writing skills. Proceedings of the 2018 CHI Conference.

Rusinovci, X. (2015). Teaching writing through process-genre based approach.) US-China Education Review, 5(10), 699-705.

Sarica, H. C., \& Usluel, Y. K. (2016). The effect of digital storytelling on visual memory and writing skills. Computers and Education, 94, 298-309.

Schank, R. C., \& Abelson, R P. (1995). Knowledge and memory: The real stroy. Lawrence Erlbaum Associates.

Schmoelz, A. (2018). Enabling co-creativity through digital storyelling in education. Thinking Skills and Creativity, 28, 1-13.

Sylvester, R., \& Greenidge, W. (2009). Digital storytelling: Extending the potential for struggling writers. The Reading Teacher, 63(4), 284-295.

Tajeri, M., Syal, P., \& Marzban, S. (2017). Enhancing vocabulary and writing skills through $I$ Manager. Journal of Educational Technology, 14(3), 40-48.

Tarigan, K. E., \& Liana. (2018). Improving students' writing descriptive text through digital storytelling technique. Budapest International Research and Critics Institute (BIRCI-Journal) : Humanities and Social Sciences, 1(3), 345-351.

Thang, S. M., Lee, Y. S., Mahmud, N., Lin, L. K., Zabidi, N. A., \& Ismail, K. (2014). Enhancing
p-ISSN 2301-7554, e-ISSN 2541-3643

https://journal.uniku.ac.id/index.php/ERJEE

21st century learning skills via digital storytelling: Voices of Malaysian teachers and undergraduates. Procedia - Social and Behavioral Sciences, 118, 489-494.

Xu, Y., Park, H., \& Baek, Y. (2011). A new approach toward digital storytelling: An activity focused on writing self-efficacy in a virtual learning environment. Educational Technology and Society, 14(4), 181-91.

Yamaç, A., \& Ulusoy, M. (2016). The effect of digital storytelling in improving the third graders' writing skills. International Electronic of Elementary Education, 9(September), 59-86.

Yang, Y. C., \& Wan-chi, I. W. (2012). Digital storytelling for enhancing student academic achievement, critical thinking, and learning motivation: A year-long experimental study. Computers \& Education, 59(2), 339-352.

Yao, N., Chen, S., \& Qian, M. (2018). Trait anxiety is associated with a decreased visual working memory capacity for faces. Psychiatry Research, 270, 474-482.

Zwart, D. P., Noroozi, O., Luit, J E. H. V., Goei, S. L., \& Nieuwenhuis, A. (2020). Effects of digital learning materials on nursing students' mathematics learning, self-efficacy, and task value in vocational education. Nurse Education in Practice, 44, 102755. 
Imam Sudarmaji, Agus Mulyana, \& Karsiyah

Applying digital storytelling to improve Indonesian high school students' visual memory and writing skill 